\title{
Revista Brasileira de Enfermagem REBEn \\ Mudanças nos relacionamentos com os amigos, cônjuge e família após o diagnóstico de câncer na mulher
}

\author{
Changes in relationships with friends, husband and family after \\ cancer diagnostic in the woman \\ Cambios en las relaciones con los amigos, conjuge y familia \\ tras el diagnostico de cancer en la mujer
}

Maria Aparecida Salci Molina

Enfermeira. Professora e Coordenadora do Curso de Enfermagem do Centro universitário de Maringá (CESUMAR), Maringá, PR. Mestre em Enfermagem pela UEM. Integrante do NEPAAF (Núcleo de Estudos, Pesquisa, Assistência e Apoio à Família). mariamolina@cesumar.br

Sônia Silva Marconi

Enfermeira. Doutora em Enfermagem. Professora do Departamento de Enfermagem da UEM, Maringá, PR. Coordenadora do Programa de Pós-graduação em Enfermagem da UEM. Coordenadora do NEPAAF.

Extraído da dissertação de mestrado "Enfrentando o câncer em família" apresentada em 2005 ao Programa de Pós-graduação em Enfermagem da Universidade Estadual de Maringá. (UEM).

\section{RESUMO}

A proposta deste estudo foi identificar mudanças ocorridas nos relacionamentos após o diagnóstico de câncer na mulher. Como estratégia teórico-metodológica foi utilizado respectivamente o Interacionismo Simbólico e a Teoria Fundamentada nos Dados. Fizeram parte da pesquisa 10 mulheres portadoras de câncer e um familiar. Identificamos que ocorreu mudanças nos relacionamentos com amigos, em que as relações que já eram íntimas consolidaram-se ainda mais e as superficiais inexistiram. Com os cônjuges, alguns relacionamentos tornaramse melhores e outros, que já eram conflituosos, passaram por vários problemas chegando até à separação. Com a família, os relacionamentos tornaram-se mais fortes. $O$ estudo nos permite compreender um contexto particular da mulher com câncer e repensar algumas estratégias de cuidados a partir dessas relações.

Descritores: Neoplasia; Saúde da mulher; Enfermagem oncológica.

\section{ABSTRACT}

The proposal of this research was to identify changes occurred in relationships after cancer diagnosis in the womam. As a theoretical-methodological strategy it was utilized respectively the Symbolic Interacionism and the Grounded Theory. Ten womam bearers of cancer and one familiar joined the research. We identify that occurred changes in the relationships with friends, the closest relations consolidated even more and the superficial ones did not exist. With the spouses, some of the relationship became better and others, that were already hard, faced a lot of problems even the separation. With the family, the relationships became stronger. The research allows us to understand a particular context of the womam with cancer and re-think some care strategies starting from these relations.

Descriptors: Neoplasms; Women's health; Oncologic nursing.

\section{RESUMEN}

La propuesta de este estudio fue a de identificar cambios ocurridos en las relaciones, tras el diagnóstico de cáncer en la mujer. Como estrategia teórico-metodológica se utilizó respectivamente el Interacionismo Simbólico y la Teoría Fundamentada en los Datos. Formaron parte de la investigación 10 mujeres portadoras de cáncer y un familiar. Identificamos que ocurrieron cambios en las relaciones con amigos, y que las relaciones que ya eran íntimas se consolidaron todavía más y las superficiales no siguieron adelante. Con los cónyuges, algunas relaciones mejoraron y otras, que ya eran conflictivas, pasaron por varios problemas llegando hasta a la separación. Con la familia, las relaciones se fortalecieron aún más. El estudio nos permite comprender un contexto particular de la mujer con cáncer y repensar algunas estrategias de cuidados a partir de esas relaciones. Descriptores: Neoplasia; Salud de la mujer; Enfermería oncológica.

Molina MAS, Marconi SS. Mudanças nos relacionamentos com amigos, esposo e família após o diagnóstico de câncer na mulher. Rev Bras Enferm 2006 jul-ago; 59(4): 514-20.

\section{INTRODUÇÃO}

O câncer é uma doença tão antiga quanto a humanidade e, ao longo da história, recebeu vários significados distorcidos da sua real fisiopatologia. Esteve durante muitos séculos associado a fatores místicos, à doença inglória advinda de castigos divinos, à doença impura, associada a precárias condições de higiene física e moral|(1,2).

A concepção de que algo ataca o corpo e provoca a devastação da vida foi sendo relativizada, à medida que as causas externas e internas da doença eram mais estudadas. A partir dos anos 50 , com os movimentos sociais feministas e mais intensivamente com os avanços nos métodos de diagnóstico e tratamento, iniciou-se uma mudança socialmente considerável nos significados e formas de enfrentamento da doença, que contribuíram para o aumento do número de sobreviventes
Submissão: 20/03/2006

Aprovação: 30/06/2006 
e do tempo de sobrevida dos pacientes ${ }^{(3)}$.

Mesmo com todos os avanços já ocorridos, ainda no século XXI, 0 câncer permanece como uma doença de causa enigmática e com tratamentos ainda não totalmente eficientes ${ }^{(3)}$. Assim, as doenças crônicas, entre elas, pode-se citar o câncer, apresentam características particulares como longo período de duração, riscos de complicações, rigoroso controle de cuidados permanentes, seqüelas e incapacidades funcionais significativas ${ }^{(4)}$. Características estas que nos fazem destacar o papel da família frente à responsabilidade, por exercer o cuidado familiar a seu membro acometido por doença.

Também é notório que o perfil epidemiológico das doenças crônicas, em especial a neoplasia, está aumentando em ritmo acelerado, representando um sério problema de saúde pública em âmbito mundial, sem distinção de região, classe social e gênero $0^{(5)}$.

Neste sentido, objetivamos compreender as mudanças ocorridas nos relacionamentos, após o diagnóstico de câncer na mulher.

\section{TRAJETÓRIA METODOLOGICA}

Como referencial teórico, optamos pelo Interacionismo Simbólico (IS) para que pudéssemos compreender o significado das mudanças ocorridas nesse contexto e, para isso, adotamos como referencial metodológico a Teoria Fundamentada nos Dados, que se caracteriza como uma abordagem qualitativa, fundamentada no IS.

Contemplando o referencial teórico-metodológico, foram respeitados os critérios de amostragem teórica e saturação teórica. Assim, fizeram parte da pesquisa 10 mulheres portadoras de câncer e um familiar que ela indicou para participar da pesquisa, constituindo-se três grupos amostrais. 0 primeiro foi composto por 5 mulheres e familiares que enfrentavam o primeiro tratamento contra 0 câncer. 0 segundo grupo, por 3 mulheres que estavam em tratamento por metástase; e o terceiro, por 3 mulheres que haviam passado por tratamento há mais de 5 anos. Uma das mulheres participou dos grupos 2 e 3.

As mulheres do estudo tinham idade de 27 a 50 anos, com níveis de escolaridade e social diversos e, embora não nos importasse a localização da doença, mas sim o significado atribuído a ela, houve predomínio do câncer de mama. Como familiares entrevistados, tivemos 4 filhas, 2 irmãs, 2 esposos, 1 mãe e 1 prima.

O contato com as mulheres ocorreu a partir dos registros em uma clínica de radioterapia situada no Noroeste do Paraná. O primeiro contato para solicitação de participação no estudo efetivamente foi por telefone, e alguns realizados na própria clínica. Os dados foram coletados no período de março a novembro de 2005, por meio de entrevistas abertas, realizadas no domicílio em dia e horário pré-agendados. Essas entrevistas foram gravadas e guiadas pela questão norteadora: "O que mudou em sua vida e na de sua família após o diagnóstico de câncer?".

O projeto de pesquisa foi aprovado pelo Comitê Permanente de Ética em Pesquisa com Seres Humanos da Universidade Estadual de Maringá (Parecer n. 045/2005). Para assegurar o sigilo das informantes, utilizamos nomes fictícios.

Este trabalho faz parte de uma dissertação de mestrado, em que os dados analisados foram organizados em 3 processos (Descobrindo a doença; Percebendo mudanças após o diagnóstico de câncer; Tendo que convier com o câncer), subdivididos por categorias e subcategorias. Os resultados que serão apresentados integram uma das subcategorias da categoria "Vivenciando mudanças secundárias", a qual pertence ao segundo processo.

\section{RESULTADOS}

Ao se perceber com câncer, o ser humano pode experienciar sentimentos de preocupação com o outro, procurando interagir da melhor forma possível com os seres presentes em seu mundo, como também com as pessoas que vêm a seu encontro. As mudanças nos relacionamentos são percebidas com relação aos amigos, ao cônjuge e com os membros da família, como apresentamos a seguir.

\section{1 mudanças nos relacionamentos com amigos}

O diagnóstico de câncer faz com que a pessoa doente medite profundamente acerca da autenticidade da amizade e, através dessas reflexões, procura afastar-se de pessoas que não se preocupam verdadeiramente com seu padecimento, permanecendo somente com os amigos autênticos.

(...) você pensa que tem amigos, assim, lógico que tem uns amigos que ficaram, amigos principalmente assim, que realmente deram apoio, mas a maioria das pessoas conhecidas, ah, isso aí você pode esquecer (Tânia).

No entender de algumas mulheres, o distanciamento dos amigos está associado ao fato de eles não estarem preparados para conviver com o portador de câncer. Isso os leva a fazer comentários impróprios. Desconsideram que os doentes necessitam de apoio e de palavras encorajadoras e não de mensagens e associações negativas, pois ao receber o diagnóstico, automaticamente, os doentes já se preocupam com o futuro:

(...) tenho amizade, converso com todo mundo, mas amizade de falar é meu amigo... Sabe, as pessoas são muito tristes. Muitos se vê você no buraco pensa que elas querem tirar você, elas querem enfiar, se você está doente a pessoa fala que você já está morta... (Gisele).

Ana Maria, outra paciente integrante da pesquisa, acredita ainda que 0 afastamento de vários amigos pode estar associado ao fato de eles terem que oferecer ajuda nesse momento e não estarem preparados psicologicamente para assumirem esse compromisso, o que creditamos a dificuldade de as pessoas enfrentarem sua própria vulnerabilidade a este processo.

(...) depois que eu descobri que estava doente, perdi muitos amigos. Minha casa era lotada de gente, todo mundo estava ali todo dia. Depois que eu passei pelo problema, eu não sei se as pessoas ficaram com medo de eu ter que pedir alguma coisa, de eu estar precisando deles, mas assim eu notei que eles se afastaram, ou de medo mesmo de encarar, não sei... (Ana Maria).

Outras mulheres percebem que: "... as pessoas se afastam de dó..." (Maria Santa), ou porque não sabem como se comportar diante delas; o que falar, como fazer visitas agradáveis ou como respeitar o desejo das mulheres de não quererem falar sobre a doença.

Agora é a hora que você precisa mais daqueles amigos, que leva a vida, pelo menos fingindo que é normal. Eu já falei: "se for para ter visitas de pessoas que não controla, que não sabe colaborar, então deixa quieto, a amizade é a mesma, eu não quero" Porque tem aquelas pessoas que vem aqui só "cutuca" na doença, quantas pessoas já ligou, falou assim: "escuta minha querida eu posso te visitar?" "Pode, contanto que não vai tocar na doença, porque eu não quero falar nada da doença, nós vamos ser normal, igual antigamente, não vamos falar nisso, pode vir, a gente toma um café junto..." e apareceu? Porque toca no assunto... (Maria Santa).

Quando encontram pessoas dispostas a oferecer ajuda, as mulheres 
reconhecem o esforço e valorizam suas atitudes, ficando muito agradecidas pelas condutas que tiveram com elas, no momento em que estavam precisando de ajuda:

Eu tenho uma amiga que ela é meu anjo da guarda, mora aqui perto, trabalhava comigo, ela é bem querida, olha é um amor de pessoa, às vezes ela vai para igreja, passa aqui: "vamos para igreja comigo", às vezes eu estou aqui ela vai para o centro "vamos passear", a gente está sempre junto. Ela fala se acontecer alguma coisa e você precisar do carro me liga, é assim, ela é super gente fina, muito prestativa, muito legal (Nathália).

Agora que está experienciando o câncer novamente, Maria Santa adquiriu uma nova concepção sobre o significado das visitas realizadas pelos amigos, dando-nos indícios importantes sobre como as pessoas devem se comportar diante de um amigo que está vivenciando um processo de doença:

Mas agora que a gente vê, que a gente erra em certas coisas. Eu acho que o certo, não era a gente, quando tem um amigo, com um problema desse, a gente ir lá visitar, o certo era a gente chamar para vir na casa da gente, falar: "eu vou te buscar, para você sair de dentro de casa um pouco, eu vou fazer uma coisa gostosa para gente comer". Agora eu vejo que o certo é isso, porque se você está lá dentro da sua casa, você está sempre deitada, feia, não é? Então é um motivo para você tirar a pessoa, dela falar, "ah, vou cortar o meu cabelo, porque tal dia vou na casa da "fulana", quero ir bonita, não quero ir com imagem de doente". Então, só agora a gente percebe tudo isso (Maria Santa).

\section{2 mudança no relacionamento com o cônjuge}

Algumas mulheres, por ocasião da descoberta do câncer, sentiramse apoiadas por seus companheiros, inclusive perceberam que 0 relacionamento entre eles tornou-se mais fortalecido:

(...) os relacionamentos se fortaleceram bastante, principalmente com o meu marido, porque ele que me deu mais apoio. Lógico que meus pais também, mas é com ele que eu convivo todos os dias (Tânia).

Sob o ponto de vista das mulheres, o sofrimento advindo da doença provocou mudança no comportamento e atitude de seus companheiros, relatando que se mesmos tornaram mais solícitos e compreensivos nos momentos difíceis do tratamento:

A gente sempre teve um relacionamento muito bom e com a doença tivemos que entender coisas que a gente não entendia e ele teve que me suportar, porque é uma fase que o emocional não tem muito controle, devido tanto medicamento, você se perde. Tem hora que você não sabe se você dormiu muito ou pouco. Mas ele soube entender, aquela fase, "Não quero sair, não estou legal", ele soube entender, eu creio que fortaleceu muito nosso relacionamento. Posso dizer que a gente é marido, mulher, amigo, companheiros, irmãos, tudo junto... (Alessandra).

Na percepção de Maria Santa, o sofrimento enfrentado com o câncer foi um aprendizado para que seu marido e ela melhorassem 0 relacionamento:

Ah! Mudou, em certo ponto mudou, mudou sim, eu ainda digo que até para melhor, em certos pontos melhorou. Mais a gente não queria que melhorasse com um sofrimento desse, ficasse então daquele jeito que estava, que já estava bom... (Maria Santa).

A melhora do relacionamento está explícita na fala de seu esposo, que demonstra muito carinho e cumplicidade, particularmente, nesse momento que ela está vivenciando o tratamento de metástase:

Eu tenho muita esperança que ela melhore, a minha esperança só morre o dia que ela morrer, se for o caso, se é que vai acontecer uma coisa dessa, se não, eu não perco a esperança e não abandono ela, morro junto se for preciso, entendeu? Mas isso de abandonar, isso eu não faço, não faço porque o que ela sofre eu sofro junto (Esposo de Maria Santa).

As mudanças ocorrem em todas as esferas, inclusive, em relação à vida íntima do casal. Maria Santa, por exemplo, faz referencias a este aspecto mas ressalta que existe por parte do esposo uma grande cumplicidade e respeito:

(...) atrapalha sim, por causa do tratamento pesado, com relação de você dormir junto, de fazer amor, atrapalha, atrapalha, mais ele não leva isso em consideração. Porque que nem esses dias, ele que estava ruim, aí ele que falava: "não, fica quieta, quieta, porque hoje eu não estou bom". Então é assim, o recíproco é verdadeiro... (Maria Santa).

Alessandra também expõe que o relacionamento sexual mudou na vida a dois devido aos tratamentos e reforça a importância de o casal manter um bom diálogo nessa fase:

Acho que a única fase que a gente teve que se ajustar foi durante 0 tratamento, porque o organismo sofre com a quimioterapia, então você não tem a mesma disposição, nem para um relacionamento sexual. Prejudica, se o marido não for compreensível, prejudica e muito. Porque ele tem necessidade, a mulher também, só que se ela está no efeito de medicamentos não quer nem saber. Aí eles precisam conversar, ele precisa entender, não forçar nada. Meu marido foi muito compreensível, não forçou nada, teve vez da gente ficar meses sem relação. Porque você termina uma quimio, dá prazo de uma semana, aí começa outra, com quinze dias você dá aquela melhorada, então nesse período de melhora, de repente até que dava para pintar um clima, mas depois já vinha o baque de novo. Tem que conversar, a mulher tem que falar para o marido o que sente: "olha eu estou sentindo dor". Porque realmente o organismo muda, ele sofre mudanças bruscas, do jeito que eu falei que feriu a minha boca, garganta, desceu para o intestino, vagina, ânus, tudo... aí lógico, você não agüenta uma relação sexual, você tem que falar "não, não dá" e conversar... (Alessandra).

No entanto, esse comportamento não é comum para todos os cônjuges. Há casos em que o comportamento deles não foi bom, sendo que a própria filha percebe e consegue identificar as mudanças ocorridas na vida dos pais, após o diagnóstico de câncer:

Melhorou no começo, depois não... eu lembro que no começo ele ficou apavorado, todo preocupado, no começo minha mãe ía na igreja ele ía junto, coisa que antes não acontecia, isso foi questão de pouco tempo, depois passou um tempo e piorou, piorou, agora está normal... (Filha de Regiane).

No caso de Nathália, o distanciamento entre 0 casal não ocorreu somente pelo comprometimento do relacionamento sexual, mas os problemas financeiros foram um fator importante na desarmonia conjugal. 
Olha, marido é um problema, primeiro eu acho ele desligado, depois nosso casamento já não era lá aquelas coisas, e agora, então, piorou, o problema aqui também é financeiro, porque antes eu estava trabalhando, e não gastando com remédio, era uma coisa e agora eu gasto muito com medicamento e tem mês que o dinheiro não dá (...) Já não estava aquela coisa, agora a gente só conversa o essencial, se conversar muito acaba brigando. A gente quase não tem relação sexual mais, porque acaba a graça, acaba tudo, ele fala que para ele é a mesma coisa, mas para mim não, não é mais, e se continuar assim, acho que vamos acabar se separando, já falei para ele. Não tem graça mais, perdeu, é a mesma coisa de quebrar uma coisa e você tentar colar aquilo, não é mais a mesma coisa (Nathália).

Ao perceber 0 afastamento do companheiro, a mulher clama por seu carinho, pois se encontra em uma fase que precisa de uma maior atenção, amparo e segurança:

(...) meu casamento ficou assim, meio balançado. Ainda conversei com o meu marido, falei assim "eu não estou tendo carinho", eu não tive carinho dele durante esse tratamento, eu não tive. Eu não sei se eu estava querendo ou se eu estava muito fragilizada por estar ali, mas eu falei para ele "eu não estou tendo carinho de você". Eu senti que ele ficou meio afastado, um pouco assim durante esse tratamento da mama (Mônica).

Ela tenta compreender o parceiro, mas não consegue devido à falta de comunicação por parte dele, chegando a duvidar da estabilidade da relação:

(...) não sei até onde vai, porque ele é muito fechado, ele não fala muita coisa que ele está sentindo. Ele não é muito de falar, então isso fica mais difícil para mim, entender a cabeça, vamos ver no que vai dar... (Mônica).

Mesmo com a solicitação da mulher, na visão do marido, os aspectos que mudaram no relacionamento conjugal estão relacionados apenas à vida sexual, pois agora ele precisa ter paciência, pelo fato de a esposa não poder engravidar e, tampouco, poder tomar pílula por ordem médica, e terem que se readequar a um novo método anticoncepcional com o qual o casal não estava habituado, e, conseqüentemente, as relações sexuais são menos freqüentes.

Ah muda! Muda um pouquinho. Muda a relação. Você tem que ter mais paciência... que nem, vamos supor na relação, você tem que ter paciência, tem os dias que você pode, tem os dias que você não pode, é... ter uma relação que nem antes, não pode, você tem que ter o cuidado, acho que é três anos que ela não pode engravidar e não pode tomar remédio, então, é tudo complicado, muda bastante, do jeito que era antes. É, dá aquele clima pesado, mais a gente, Graças a Deus estamos superando... (Esposo de Mônica).

No depoimento a seguir, ele esclarece que não deseja separar-se da esposa, pelo contrário. Embora ocorra subjetividade dos problemas no relacionamento, seus significados com relação ao casamento não Ihe permitem pensar em separação pelo motivo da doença, mesmo tendo vivenciado mudanças na vida íntima e a esposa ter proposto isso.

(...) nós sentamos, conversamos, até ela falou assim, se você não quiser mais, você leva a sua vida. Eu falei não, por enquanto eu não quero isso não, se chegar um dia acontecer isso, não vai ser por causa da sua doença, vai ser por causa de outra coisa, não vai ser por causa da sua doença que vou deixar de viver com você [...] a gente conversou bastante, desde o início, conversamos. Aí eu falei: "não, a gente está junto nessa, a gente vai encarar mais uma". A gente já tem uma filha, a coisa mais linda do mundo, então para que isso, vamos passar dessa vida para outra e vamos levar junto, para que sair fora, agora não é hora disso. Porque a gente sabe de muitas pessoas que diz: ah, a mulher de fulano está com câncer, e ele separou dela. Eu falei: "não, por quê?" Vamos ficar junto! (Esposo de Mônica).

Percebemos a insegurança de Mônica, concernente à estabilidade do relacionamento. Aparentemente, ela ficou mais carente emocionalmente. Esperava mais apoio do parceiro, fato não percebido por ele, pois em seus relatos ele afirma ter se empenhado desde 0 início para que ela ficasse boa. Diz que buscou ajuda de várias pessoas, na empresa que trabalha. Chegou a vender o único carro do casal para custear o procedimento cirúrgico a que ela foi submetida no início do tratamento, visto que pelo SUS demoraria a ocorrer e havia o medo de a doença evoluir.

(...) a situação financeira não ajudava na época, aí, pega daqui, pega de lá. Todo mundo ajudou, a primeira vez foi particular, a gente não esperou a doença avançar mais, o primeiro médico falou que era mesmo "o perigoso", aí nossa, um ajuda o outro, o pessoal da firma me ajudou muito. Como eu trabalho de caminhão nós temos um rádio, a gente conversa com os amigos pelo rádio, o pessoal se reuniu para ajudar, até que a gente conseguiu. A primeira cirurgia a gente fez tudo, ai depois foi pelo SUS. Eu vendi o carro para fazer esse tratamento dela, mas a gente vai, se Deus quiser a gente vai voltar o que era antes e desse ano não vai passar sem eu por outro carro na garagem... (Esposo de Mônica).

No entanto, quando a relação já está abalada, se não existir ausência de carinho mútuo entre o casal, o relacionamento pode tornar-se mais enfraquecido, ao surgirem grandes problemas. Isso gera, na informante, sentimentos hostis ao esposo:

(...) da primeira vez, eu e o meu marido quase nos largamos, ah... Parece que ficou meio assim... você imagina que eu fiquei quase 2 anos sem ter relação sexual com ele. Parece que peguei implicância com ele. É, eu sou sem paciência, ele tem paciência, mas eu não tenho... Agora [depois do segundo diagnóstico] essa vez parece que nem tanto, mas a outra vez eu peguei raiva parece, não sei... (Gisele).

E, nesses momentos difíceis, a suspeita de traição estremece ainda mais o relacionamento:

Eu não sei, e ainda saiu uma conversa que ele estava andando com uma menina, era tudo mentira, e aquilo foi bem na época, então aquilo me deixou meia... Pouco tempo agora que a gente está melhor, eu não conversava direito com ele mais, não tem um ano que a gente começou a conversar; eu não saia mais de casa com ele... (Gisele).

Quando a desconfiança da traição se torna real, a mulher sente-se humilhada, relatando que o sofrimento sentido com a atitude do marido foi mais intenso do que o padecimento com o câncer:

(...) no início do tratamento mudou, não sei se nesse meio tempo, que homem é homem, e eu tinha o tratamento e não podia ter relação, eu não sei se foi nesse meio tempo, ele se perdeu. Ele é muito bom, me deu muito apoio, ia todos os dias na rádio comigo, sempre junto, 
nunca me abandonou em nada, mas nesse meio tempo... quando eu descobri, eu falei:" Isso eu não esperava dele". Eu já sofri muito, não pela doença, mas por esses motivos, para mim foi mil vezes pior saber da traição. Quer coisa pior que traição? Eu passei esse problema com a doença, aí vem a traição, eu falei: Ah não, traição para mim?, olha, mil vezes pior que a doença. Se eu estou com um problema de saúde eu vou ao médico, agora a traição... para mim foi pior que a doença... (Regiane).

O relacionamento pode ficar insustentável a ponto de ocorrer uma separação:

(...) perdi até o marido. Não vou dizer para você que meu casamento era uma maravilha, porque não era, só que assim eu estava ativa a tudo, eu fazia, eu acontecia e de repente quando eu não podia mais que tinha que ser ele, ele não teve força, para cuidar de mim, cuidar da casa, cuidar da minha filha... (Ana Maria).

Ana Maria atribui o rompimento do relacionamento à doença, ou seja, aos momentos em que vivenciava os efeitos colaterais do tratamento e não conseguia ser a mulher de antes e ainda precisava receber ajuda.

(...) eu tinha aquela vaidade tremenda sabe, em estar bonita para o mundo, e o que aconteceu? Eu fiquei careca, o meu marido arrumou uma menina de 19 anos, e eu fazia quimioterapia, eu ficava lá no meu quarto vomitando, ele pegava o colchão e ia para sala dormir, mostrava que tinha nojo de mim (Ana Maria).

No discurso a seguir, a informante expõe suas dificuldades, pois além do sofrimento pelo câncer e pelo tratamento, ela teve que passar por situações humilhantes com o parceiro descomprometido, até que a separação conjugal ocorresse concretamente:

(...) ele me agredia, às vezes, ele queria que eu levantasse para fazer comida para ele de madrugada, quando ele chegava. Ele bebia, saía com outras mulheres, não me ajudava nas despesas de casa, olha até eu entender que eu tinha que me separar mesmo. Então fo um ano que eu sofri muito. Agora quando a gente se separou eu estava terminando as quimioterapias, ai quando eu vi, falei ..."puxa, agora que eu estou terminando meu tratamento, ele não ficou comigo na doença, agora que eu estou terminando eu não quero mais...", daí eu tomei uma decisão e me separei (Ana Maria).

No mesmo mês em que Ana Maria se separou, reencontrou seu primeiro namorado na igreja que começou a freqüentar; logo depois, eles se reconciliaram e ele teve um papel importante como companheiro, no momento em que sua auto-estima estava baixa em virtude das agressões verbais do ex-marido. Esse relacionamento trouxe de volta sua auto-estima como mulher, revelada neste depoimento:

Quando eu tinha 12 anos eu conheci ele, namorei com ele dos 12 aos 17 anos só que ele era drogado. Aí eu me separei, falei para ele que não queria mais, que não dava mais... ele foi meu primeiro homem. Ele gostava muito de mim e eu também queria me casar com ele, tinha aquele sonho, mas eu não queria, por causa do problema dele com as drogas. Ai depois que o meu marido foi embora, um dia eu estou dentro da igreja e encontro com ele, já fazem 5 anos que ele está na igreja, ele é evangélico, nunca casou, nunca teve filhos... Fiquei 11 anos sem vê-lo, larguei dele conheci meu marido e casei, fiquei com meu marido todo esse tempo, ai depois que meu marido foi embora, que a gente se separou eu reencontrei ele. Ele nunca me esqueceu, nossa, faz de tudo por mim, de tudo, sabe quando eu precisava ir no médico, ele ia no médico comigo. $E$ assim, o meu marido falou muita coisa, falou que eu estava feia, que eu estava careca, e de repente encontrar uma pessoa que sabe, que me colocasse lá em cima, falava que eu estava bonita, nossa, isso me ajudou muito... (Ana Maria).

No entanto, quando Ana Maria descobriu a metástase, voltou a repensar a situação. Vislumbrando novamente a possibilidade da morte, ela optou por separar-se desse namorado, para se dedicar mais à filha e organizar algumas coisas antes de morrer, como, por exemplo, aproximar a filha do pai, pois achava importante deixar a filha com uma referência, caso ela realmente viesse a falecer:

Eu me separei, por causa da minha filha, eu pensei muito nela, na cabecinha dela, ela gosta muito do pai, ela é muito novinha, e eu também não estou com cabeça para pensar nisso agora, aí eu falei para ele que não, que agora eu tinha que cuidar da minha filha, dar para ela o amor que ela precisa, ter todo o tempo da minha vida para ela e que eu não queria mais, que eu queria, pelos menos nesse tempo para não ter mais aquela briga e discussão, fazer aquela ligação de pai e filha (Ana Maria).

\section{3 mudanças nos relacionamentos familiares}

Para as mulheres, as alterações identificadas nos relacionamentos com a família provocada pela convivência com o câncer tiveram grande importância em suas vidas. Isso porque o papel da família é o de assumir seus membros quando acometidos por doença e, nessa perspectiva, as mulheres tiveram muito apoio e acolhimento de seus familiares, “... nessa hora, quem fica do lado da gente mesmo é a família, mas é ela mesmo que dá apoio..." (Tânia).

Com o cuidado dispensado nesse momento pelos membros da família, elas acabam por valorizá-los ainda mais, percebendo que esses são os relacionamentos verdadeiramente duradouros e sinceros:

Eu sei que eu conheci verdadeiramente quem é minha família, que ela me ama de verdade, que é a minha mãe, meus irmãos, minha avó, meus tios... Então foi ai que eu aprendi que tinha que dar valor nas pessoas que estavam aqui e são minhas raízes, que elas continuavam aqui... (Ana Maria).

A preocupação dos entes queridos com a saúde dessas mulheres, também ficou mais visível. Tornaram-se mais atenciosos e presentes, aumentando assim o vínculo afetivo e tornando-se mais acolhedores, como demonstra o depoimento:

(...) a preocupação que eles têm com a gente, muda demais. Só não muda ainda mais, porque cada um tem a sua vida, se não, todo mundo vinha correndo ali ficar juntinho de você o tempo todo (Maria Santa).

Na percepção de Mônica, a doença que Ihe trouxe sofrimento e muita angústia também fortaleceu os laços afetivos familiares, pois ela percebeu em cada familiar manifestações de solicitudes:

Olha, eu acho assim, que depois que eu fiquei doente, teve mais contato, sabe? Entre eu, entre eles, mãe, minha irmã, teve mais contato, muito mais. Eles estão sempre preocupados, sempre ligam, sempre querendo saber como é que está, como está os exames, como é que foi. Então, o que influenciou foi mais isso, a gente ficou com mais contato, mais junto, mais preocupado, eles têm muita preocupação e sempre quando eu tenho que ir ao médico, eles no 
outro dia já ligam para saber como é que foi, antes não era assim... (Mônica).

Neste estudo, Tânia foi a única mulher a relatar a ocorrência de aumento no vínculo afetivo com a família do esposo "aproximou muito, minha sogra me deu muito apoio", justificando que a religiosidade foi 0 principal fator de aproximação entre ambas:

Ela é ministra da Igreja, ela é de rezar muito, eu não tinha tanta fé assim. Eu acreditava, eu ia à missa, mas não tinha aquela fé que ela tem. Ela vinha aqui trazer comunhão para mim, vinha rezar para mim, então, nos aproximamos muito, muito. Nosso relacionamento fortaleceu bastante (Tânia).

Os familiares também entenderam que o vínculo aumentou em virtude da doença: "mudou, a gente ficou ainda mais próximo" (Irmã de Camila), até mesmo com a filha.

Eu acho que a gente ficou mais amiga, porque tem gente que acha que pais e filhos não podem ser amigos, porque eles tem que ser os pais e, filho ser filho, mas não, ela é enérgica quando tem que ser, eu vou aceitar, porque claro eles têm mais bagagem e mais sabedoria, mas só que a gente se tornou mais amiga, a gente se abre mais, conversa mais, o que eu conto para ela, eu conto para uma amiga minha, a gente senta na cama conversa, troca idéias, isso eu acho que foi um benefício, porque, se não fosse a doença, talvez a gente não teria essa união (Filha de Alessandra).

A relação de amor nos vínculos familiares é essencial para todos os membros envolvidos. Para a prima de Ana Maria, esse é o papel da família, o de estar junto da mulher, para ajudá-la a se fortalecer para enfrentar a doença.

Então, hoje eu vejo que a união da família é essencial, essencial, que não é uma união de festa, é uma união de amor, porque festa tem sempre, não precisa ser família para estar unido, mas o amor é essencial da família, é importante ela estar em volta, em torno, querendo ajudar, querendo tudo. Porque se não fosse o amor, a paciência, a vontade de ver aquela pessoa viva, de ver aquela pessoa vencer, de ver aquela pessoa em pé (...) o câncer é uma doença que vem, destrói a pessoa se a pessoa não for forte não tiver uma família que apóia, porque a família é muito importante, muito importante nesse momento... (Prima de Ana Maria).

Mesmo a família que mora em outra cidade participa e não renuncia a seu papel de cuidadora, pois busca formas de vivenciar o processo, mesmo à distância, já que vem ao encontro de seus membros:

(...) a maioria dos meus irmãos não moram aqui, mas graças à Deus nesse ponto todos vieram aqui, eles ficaram preocupados, principalmente minha mãe. Eu não esperava que eles iam vir todos aqui, não esperava mesmo que eles viriam. Achei que eles iam ficar por telefone. Mas eles vieram, vieram todos, todos, todos os meus irmãos vieram, uns que não puderam vir no mesmo dia, na outra semana vieram, todos vieram... (Mônica).

Nesses contatos, mesmo por telefone, ocorre a transmissão de palavras positivas, o que é muito importante, pois a mulher se sente fortalecida com a atenção e o amor da família para enfrentar a doença, como revela a depoente:

Eles me deram mais atenção, se eles me ligavam uma vez, agora me ligam duas... (Nair).

Esse comportamento da família faz com que as mulheres se sintam mais amadas, valorizadas e fortalecidas.

Eu percebi que eles me deram mais atenção e me valorizam mais, eles não ficaram desesperados, eles estão muito contentes, de ver que eu superei, eles estão contentes, todos na minha família está contente de ver que eu superei... (Nair).

Quando a mulher fica deprimida, é a família que identifica a necessidade de se fazer presente, unindo-se e envolvendo-se para poder ajudá-la a suportar essa fase de angústia:

Ah, eu acho que o que mais mudou foi que a gente se envolveu mais, teve que dar mais atenção e apoio todo dia, porque ela entrou em depressão, no início ela entrou em depressão e então a gente teve que ficar sempre junto dela... (Mãe de Tânia).

Nesse sentido, os familiares buscam estar próximos, porque percebem o sofrimento da mulher e também sofrem com ela. Têm medo do que o futuro lhes reserva e assumem, então, uma postura de autocobrança para oferecer suporte emocional por meio da companhia:

(...) ela está entrando em estado de depressão, ela não fala isso, mas ela está começando a entrar, qualquer coisa é motivo para ela chorar, ela fica desesperada, ela tem medo de morrer. E a gente sofre com isso ela pensa que não, mas só que a gente sofre do mesmo jeitinho que ela, só que ela acha que a gente não está preocupado com ela, que a família não está, eu sinto e muito sabe, eu estou querendo largar do meu serviço para me dedicar a ela, me dedicar a isso, porque a gente não sabe o que pode acontecer, se uma coisa 'boba' pode ficar mais séria mais para frente, sabe o que pode acontecer. Então eu tenho que fazer o melhor agora, porque depois se não tiver jeito, a gente não pode falar que não tentou... (Filha de Nathália).

Da mesma forma que os familiares conseguem identificar mudanças no comportamento da mulher, ela também consegue perceber o que sua família está sentindo em relação a ela, quando ocorreu a metástase e vivenciava as complicações do câncer:

(...) minha família sempre foi muito unida, sempre teve muita ligação. Agora eles estão muito desesperados, eu sinto, no olhar, no jeito deles, a dó, a compaixão... (Ana Maria).

Em uma fase de aceitação da doença, a mulher doente consegue apoiar seus familiares, tranqüilizando-os e preparando-os para aceitar a doença e, talvez, a sua morte, sem desespero, como uma fase normal do ciclo evolutivo:

(...) eu falo para eles... eu não quero que eles fiquem chorando e se revoltem. Agora eles estão parando um pouco, mas antes, às vezes eu ficava mais preocupada com eles do que comigo (...) o meu irmão só chegava perto de mim chorando, aí eu falei para ele que eu não quero que ele fique chorando, quero que creia somente em Deus, não quero que se revolte... (Ana Maria).

Mesmo aceitando que a morte é algo inevitável, Maria Santa tenta preparar os filhos para a vida, caso venha a faltar-lhes. Sempre que tem oportunidade, cita exemplos que conhece e solicita aos filhos que um sempre cuide do outro: 
(...) as crianças, nossa, a menina chora dia e noite. Mas ela procura sair, estudar... porque eu sempre falei para eles, "a gente não pode esperar nada de ninguém, é a gente que tem que correr atrás". Então, não vai ser porque mãe morreu, mãe tem isso ou aquilo, que vocês não vão ser grandes pessoas na vida (...) ainda eu cito exemplo de uns vizinhos nossos, que a mãe morreu em acidente e os deixou, 0 menino tinha um aninho, a menina não tinha três. A menina já fez faculdade lá em Santa Catarina e o menino também está fazendo faculdade boa, a menina casa esse ano. Inclusive eu falo, sempre eu falo: "olhe lá o G e a $L$, como é que é", porque os dois são agarradinhos, agarradinhos um no outro. Eu falo: "vocês tem que ser assim, desse jeito, estar sempre um cuidando do outro" e pelo jeito eu não sei não, se tudo não está levando a ser assim... (Maria Santa).

\section{DISCUTINDO OS RESULTADOS}

A experiência face às mudanças nos relacionamentos compreende os contextos de amizade, matrimônio e família. Com relação aos amigos, percebemos que os relacionamentos que já eram mais consolidados permanecem e se fortalecem com o advento do câncer, proporcionando bem estar à mulher e à família. Contudo, aqueles relacionamentos que já eram problemáticos ou superficiais, muitas vezes, não resistem e, às vezes, tornam-se prejudiciais para a mulher, pois afetam o seu emocional.

Com relação ao cônjuge, o câncer da esposa influenciou nos relacionamentos abalados anteriormente. Ocorreu uma desestruturação ainda maior. Passaram por inúmeros contratempos, como, por exemplo, traição conjugal por parte do esposo, provocando até mesmo a separação. No entanto, outros relacionamentos alcançaram maior maturidade, por meio do diálogo entre os casais, o que fortaleceu a relação.

Algumas mulheres percebem que 0 fato de a relação sexual encontrar-se prejudicada em virtude dos tratamentos pode ser o pontochave das discórdias do casal. Para os homens, o prazer sexual tem bases fisiológicas e as relações sexuais são estimuladas pela formação das células dos espermas e do fluido nos canais seminais. 0 oposto acontece com as mulheres, que têm o desejo sexual estimulado por bases emocionais e não físicas; assim, o estímulo dependerá do fato de ela se sentir amada, admirada e apreciada por seu companheiro(6).

A ocorrência do câncer pode trazer ao casal problemas de sexualidade, uma vez que os aspectos psicológicos não contribuem para um bom desempenho sexual e em certos momentos a debilidade física pode acontecer, uma vez que também o parceiro pode considerar a mulher doente excessivamente frágil para uma relação sexual(7).

A união da família também esteve em destaque, após o diagnóstico de câncer. E o fortalecimento dos laços familiares foi muito importante para amenizar o sofrimento nos momentos em que o doente mais precisava: "os familiares estão dispostos a fazer qualquer coisa que venha a favorecer o doente, porque se sentem responsáveis e solidários pelo mesmo"(8).

Os relacionamentos com a família de origem se tornaram mais consolidados, constituindo fonte de apoio, segurança e estabilidade emocional para a maioria das mulheres. Normalmente, toda a família mobiliza-se para acolher, confortar, cuidar e acompanhar a mulher em sua trajetória com o câncer. Interessante, nesse aspecto, é que mesmo a família que mora longe consegue fazer-se presente, utilizando algumas estratégias de comunicação para estar mais próximo da mulher.

Sales ${ }^{(9)}$, trabalhando com pessoas portadoras de neoplasias nos domicílios, pontua a ocorrência de sentimentos de ambivalência, pois, ao mesmo tempo em que o portador de câncer se sente angustiado ao perceber que sua doença traz sofrimento para seus familiares, sentemse também aliviados e alegres por tê-los ao seu lado.

Contudo, quando debilitadas fisicamente e tendo que deixar de oferecer o cuidado físico aos membros familiares devido à trajetória vivida pelos tratamentos, às vezes, longos e incapacitantes, as mulheres, ainda assim, continuam assumindo o papel de cuidadora. Preocupam-se com o estado emocional dos membros, principalmente dos filhos. Nesses casos, mesmo sentindo-se angustiadas, elas tentam transmitir tranqüilidade para não deixá-los ainda mais preocupados, para que continuem exercendo suas funções sociais normalmente. Assim, quando acometidas pelo câncer, elas tentam se reorganizar para continuar assumindo suas funções dentro do contexto familiar, em especial, a de cuidadora.

\section{CONSIDERAÇÕES FINAIS}

O processo de vivenciar uma doença grave em alguma fase da vida está permeado de alterações significativas no cotidiano. Esse fato não ocorre somente com quem adoece, mas se estende a todos os membros envolvidos no contexto familiar e até social.

Esperamos que este estudo desperte em toda a população, de forma geral, um direcionamento diferenciado de como realizar visitas e assistir um amigo portador de câncer. Assim, trabalhar com mulheres com câncer consiste em estender o cuidado para além dos assistenciais e técnicos, voltando-se para um apoio emocional, particularmente na fase de enfrentamento do câncer. Isso exige do profissional também um "exercício", para desenvolver a habilidade de assistir todos os integrantes da família da mulher doente de maneira única e solícita.

\section{REFERÊNCIAS}

1. Sant'Anna DB. A mulher e o câncer na história. In: Gimenes MGG Fávero MH. A mulher e o câncer. Campinas (SP): Livro Pleno; 2000. p. 43-70.

2. Malzyner A, Caponero R, Donato EMOD. A metamorfose de uma angústia: o tratamento do câncer da mama de Halsted ao BRCA 1. In: Gimenes MGG, Fávero MH. A mulher e o câncer. Campinas (SP): Livro Pleno; 2000. p.71-107.

3. Tavares JSC, Trad LAB. Metáforas e significados do câncer de mama na perspectiva de cinco famílias afetadas. Cad Saúde Pública 2005; 21(2): 426-35.

4. Marcon SS, Waidman MAP, Carreira L, De Cesário MN. Compartilhando a situação de doença: o cotidiano de famílias de pacientes crônicos. In: Elesen I, Marcon SS, Santos MR. O viver em família e sua interface com a saúde e a doença. Maringá (PR): Eduem; 2002. p. 311-35.
5. Organização Mundial da Saúde. Cuidados inovadores para condições crônicas: componentes estruturais de ação. Relatório Mundial. Brasília (DF): OMS; 2003.

6. Chapman G. As cinco linguagens do amor: como expressar um compromisso de amor a seu cônjuge. São Paulo (SP): Mundo Cristão; 1997.

7. Tiblier KB. The family and cancer. In: Gilliss CL. Toward a science of family nursing. New York (NY: Addison-Wesley; 1989. p. 33243.

8. Bielemann V. O ser com câncer: uma experiência em família (dissertação). Florianópolis (SC): Universidade Federal de Santa Catarina; 1997.

9. Sales CA. O cuidado no cotidiano da pessoa com neoplasia compreensão existencial (tese). Ribeirão Preto (SP): Escola de Enfermagem de Ribeirão Preto, Universidade de São Paulo; 2003. 